(Katolicki Uniwersytet Lubelski Jana Pawła II, e-mail: mkoper@kul.lublin.pl)

ORCID: 0000-0002-9878-0820

\title{
NOKAUT JEST TU NIEUNIKNIONY JAK ZMARSZCZKI PO SZEŚĆDZIESIĄTCE. KILKA UWAG O KONSTRUKCJACH PORÓWNAWCZYCH W MÓWIONYCH WARIANTACH WYPOWIEDZI DZIENNIKARZA SPORTOWEGO ANDRZEJA KOSTYRY
}

\section{WPROWADZENIE}

Studia nad językiem sportu w Polsce maja już kilkudziesięcioletnią tradycję. Za ich ojca należy uznać Jana Ożdżyńskiego, chociaż pierwsze przyczynkarskie publikacje na ten temat ukazywały się dużo wcześniej. ${ }^{1}$ Współcześnie można mówić o pewnym renesansie badań nad tą odmianą języka. Podyktowane jest to $z$ jednej strony atrakcyjnością tej problematyki, bogactwem korpusowym tekstów sportowych (zarówno mówionych, jak i pisanych), z drugiej zaś modą na językowa potoczność i żywą, bardzo często ekspresywną mową dziennikarzy sportowych, w której można doszukać się wielu interesujących cech idiolektalnych, nierzadko z czasem mających wpływ na ogół zachowań językowych Polaków. Tę ostatnią kwestię widać szczególnie we wpływie leksyki sportowej na inne odmiany polszczyzny. ${ }^{2}$ Obserwujac pisane oraz mówione warianty wypowiedzi dziennikarzy sportowych, należy zatem skonstatować, że ich medialny charakter znajduje czasem odzwierciedlenie w potocznym i oficjalnym rejestrze języka. Ponadto wielu dziennikarzy telewizyjnych, radiowych, internetowych oraz prasowych poszukuje własnego stylu sprawozdawczego. Widać to bardzo często w ich wyszukanych konstrukcjach, innowacjach frazeologicznych, skrzydlatych słowach, peryfrazach, z których

1 Stan badań nad językiem sportu oraz bibliografię prac przedstawiłem w jednym ze swoich artykułów. Zob. M. Koper, Język sportu - problematyka badawcza [w:] A. Czapla, M. Koper (red.), Język $i$ sport, Lublin 2016, s. 13-40. Należy jednak zaznaczyć, iż w ostatnich latach pojawiło się kilkanaście nowych publikacji.

2 J. Podracki, Wpływ słownictwa sportowego na inne odmiany polszczyzny, „Kultura Fizyczna” 1978, nr 6, s. 265-269; L. Zieliński, Wpływ słownictwa sportowego na język polityki [w:] G. Szpila (red.), Język a komunikacja 4. Zbiór referatów $z$ konferencji pt. Język trzeciego tysiąclecia II (Kraków, 28 lutego-2 marca 2002), t. I: Nowe oblicza komunikacji we współczesnej polszczyźnie, Kraków 2002, s. 261-270. 
część jest bardzo oryginalna, inna zaś graniczy $z$ językowym kiczem. ${ }^{3}$ $Z$ pewnością barwny język sportu, jego emocjonalny charakter, kreatywność i wyobraźnia użytkowników sprawia, że coraz częściej staje się on przedmiotem refleksji lingwistycznej.

W ostatnich kilkunastu latach studia nad ta odmiana języka skupiały się głównie na analizie mówionych wariantów wypowiedzi dziennikarzy sportowych. Nieco mniejsza uwaga cieszyły się badania prasowe lub internetowe. Szczególnie w obszarze badań idiolektalnych, czyli tych, które poświęcone są osobliwościom językowym konkretnego dziennikarza sportowego, jest jeszcze wiele materiału do interpretacji. W mniejszym też stopniu autorzy prac $z$ zakresu leksyki sportowej analizowali słownictwo specjalne samych sportowców i kibiców. Należy jednak podkreślić, że i w tym aspekcie luki badawcze sa sukcesywnie zapełniane. Powstaje bowiem coraz więcej prac na temat odmian socjolektalnych poszczególnych dyscyplin sportowych (m.in. piłki nożnej, kolarstwa, siatkówki, skoków narciarskich) oraz języka środowisk kibicowskich. ${ }^{4} Z$ drugiej strony, obserwując współczesne trendy, można zauważyć, iż językoznawcy coraz częściej za cel swoich badań stawiają analizę genologiczną oraz sportowy dyskurs w mediach. ${ }^{5}$ Pojawiaja się wreszcie prace niedotyczace sensu stricto języka sportowego, ale będące niejako owocem lingwistycznej refleksji na tle bieżących wydarzeń sportowych, takich jak igrzyska olimpijskie czy mistrzostwa świata. Tego typu publikacje określam mianem obrzeży języka sportowego. ${ }^{6}$ Podsumowując ten krótki przegląd prac o ję-

3 Zob. B. Grochala, Kicz jako sposób wyrażania emocji (metaforyka radiowych relacji sportowych) [w:] B. Kudra, E. Szkudlarek-Śmiechowicz (red.), Kicz $w$ języku i komunikacji, Łódź 2016, s. 335-342.

4 Można do nich zaliczyć m.in. publikacje Stefana Wiertlewskiego, poświęcone socjolektowi rowerowemu, Wioletty Kochmańskiej o języku siatkówki w odmianie środowiskowo-profesjonalnej i wewnątrzśrodowiskowej czy też prace Katarzyny Gilety-Klępki o języku kibiców. Zob. M. Koper, op. cit., s. 13-40.

5 B. Grochala, Telewizyjna transmisja sportowa jako kolekcja gatunków [w:] D. Ostaszewska, J. Przyklenk (red.), Gatunki mowy i ich ewolucja, t. 5: Gatunek a granice, Katowice 2015, s. 347-355; tejże, Telewizyjna transmisja sportowa w ujęciu genologii lingwistycznej na materiale meczów piłki nożnej, Łódź 2016; I. Loewe, Sport $w$ mediasferze $z$ perspektywy lingwisty, „Postscriptum Polonistyczne" 2014, nr 2 (14), s. 71-91; tejże, Sport, medium, dyskurs telewizyjny. Mediolingwistyczne rozważania o wpływie, "Zeszyty Prasoznawcze" 2020, t. 63, nr 2 (242), s. 31-46.

6 Bardzo często sa to prace $z$ zakresu poprawności językowej, kultury języka i stylistyki. Zob. Z. Gałecki, Slavek i Slavko - nazwy maskotek Mistrzostw Europy w Piłce Nożnej 2012, „Roczniki Humanistyczne” 2012, t. LX, z. 6, s. 87-95; tegoż, „Czyste szaleństwo”- współczesna piosenka okolicznościowa. Liber i zespót InoRos [w:] J. Kuć, K. Wojtczuk (red.), Język a muzyka. Ujęcie filologiczne i muzykologiczne, Siedlce 2014, s. 23-29; M. Koper, Polska dawaj! O języku pitkarskiego hasła oraz jego bliższych i dalszych konotacjach, „Poradnik Językowy” 2019, z. 1, s. 95-105. 
zyku sportu, można skonstatować, iż w początkowym okresie refleksji lingwistycznej nad ta odmiana języka dominowało głównie ujęcie strukturalistyczne, w następnych etapach zaś socjolingwistyczne, pragmalingwistyczne, tekstologiczne oraz mediolingwistyczne.

Przedmiotem niniejszego artykułu jest analiza wybranych mówionych wariantów wypowiedzi Andrzeja Kostyry. Materiałem źródłowym wykorzystanym na potrzeby niniejszego szkicu sa relacje $z$ walk bokserskich $z$ ostatnich kilkunastu lat. Zostały one zgromadzone przez autora niniejszego artykułu bądź też wynotowane $z$ wybranych witryn internetowych. ${ }^{7}$ Przywołany w tytule tego tekstu A. Kostyra jest nie tylko popularnym dziennikarzem prasowym, ale też dobrze rozpoznawalnym komentatorem sportowym specjalizującym się głównie w boksie zawodowym oraz w futbolu amerykańskim. Swoją karierę dziennikarska rozpoczą w latach 90. XX wieku, kiedy był korespondentem Telewizji Polskiej na Igrzyskach Olimpijskich w Barcelonie w 1992 roku. Już wtedy relacjonował zmagania bokserskie. W kolejnych latach współpracował m.in. z Wizja Sport i Polsatem Sport. Swoje artykuły zamieszczał również w „Przeglądzie Sportowym”. Obecnie jest szefem działu sportowego w „Super Expressie". Prowadzi także kanał na YouTube o tematyce bokserskiej - Kostyra SE. Ponadto warto odnotować, iż jest autorem pozycji książkowej pt. Walki stulecia. Bohaterowie wielkiego boksu. ${ }^{8}$

$\mathrm{W}$ relacjach $\mathrm{z}$ aren bokserskich A. Kostyra posługuje się barwnym, nieszablonowym i sugestywnym językiem. Ze względu na te cechy część środowiska kibiców określa go mianem Paganiniego sportowego mikrofonu. ${ }^{9}$ Jedna $z$ najbardziej charakterystycznych cech językowych tego dziennikarza jest stosowanie konstrukcji porównawczych. Obserwując bogactwo komparatywów, można zaryzykować stwierdzenie, iż jest to główna i najbardziej rozpoznawalna cecha jego profesjololektu. Wprawdzie nagromadzenie porównań $\mathrm{w}$ relacjach to jeden $z$ podstawowych wyznaczników współczesnego języka sportowego w odmianie środowiskowo-profesjonal-

$7 \mathrm{~W}$ ostatnich kilkunastu latach wielu internautów gromadzi materiał leksykalny wybranych dziennikarzy sportowych. Charakteryzuje się on barwnościa opisu widowisk sportowych, skłonnościa do parodii, humoru. Autorzy odnotowują też w nim błędy językowe. Nierzadko jednak zgromadzony przez nich materiał nie jest do końca wiarygodny oraz rzeczowo bywa słabo udokumentowany. Przy korzystaniu ze źródeł internetowych autor niniejszego tekstu szczegółowo weryfikował autentyczność korpusu wypowiedzi mówionych, opierając się na własnych doświadczeniach oraz obserwacjach transmisji telewizyjnych.

8 A. Kostyra, Walki stulecia. Bohaterowie wielkiego boksu, Kraków 2017.

9 Konstrukcje peryfrastyczne, dzisiaj w języku mediów bardzo modne, są także charakterystyczne dla języka sportowego. Najczęściej wyrażeniami omownymi określani sa sportowcy, rzadziej drużyny, areny sportowe itp. Zob. M. Koper, Peryfrazy w języku komentatorów sportowych, „Roczniki Humanistyczne" 2012, s. 113-122; przedruk [w:] M. Kita, I. Loewe (red.), Język w telewizji. Antologia, Katowice 2016, s. 217-226. 
nej, niemniej jednak w opinii piszacego te słowa nie ma drugiego dziennikarza, który tak często i z takim przywiąaniem posługiwałby się tymi konstrukcjami. Poza tą dominantą w języku A. Kostyry występują również inne wyznaczniki stylowe. Należy do nich m.in. rozbudowana szata metaforyczna, peryfrastyczność wypowiedzi, dygresyjność, skłonność do ironii, sarkazmu, prowokowanie treści drażliwych, łamiących językowe tabu, kolokwialność, naturalistyczne obrazowanie czy też przejawy świadczące o brutalizacji wypowiedzi. Ostatnia $z$ cech ma swoje usprawiedliwienie $\mathrm{w}$ tym, że sam boks zawodowy jest jednym $z$ najbrutalniejszych sportów walki. $Z$ uwagi na ograniczenia redakcyjne omówiona będzie jedynie zróżnicowana warstwa komparatywów w języku A. Kostyry. W dalszej części niniejszego artykułu kolejno zostanie przedstawiona charakterystyka formalna porównań, semantyka komparacji, uwzględniająca człon porównujący i porównywany, funkcja komparatywów oraz próba ich ogólnej oceny. Artykuł kończy krótkie podsumowanie.

\section{STRUKTURA PORÓWNAŃ}

Literatura przedmiotu dotyczaca porównań w tekstach literackich i użytkowych jest bardzo obszerna. ${ }^{10}$ Sukcesywnie pojawiają się nowe opracowania dotyczacce komparatywów. Również język sportu doczekał się kilku pozycji na ten temat. Jedna $z$ kluczowych publikacji jest praca Katarzyny Burskiej, dotyczaca konstrukcji porównawczych jako przejawu językowej kreatywności dziennikarzy sportowych. ${ }^{11} \mathrm{Na}$ rolę kom-

10 Zob. m.in. B. Mikołajczak, Porównania w „Faraonie” Bolesława Prusa, „Studia Polonistyczne” 1976, s. 105-114; D. Buttler, Porównania w twórczości "Żeromskiego [w:] Z. Goliński (red.), Stefan Żeromski. W pięćdziesiata rocznice śmierci. Studia i szkice, Warszawa 1977, s. 258-276; K. Siekierska, Porównania $w$ „Wojnie chocimskiej” Wacława Potockiego i w „Pamiętnikach” Jana Chryzostoma Paska, „Polonica” 1981, t. VII, s. 233-254; Z. Mokranowska, Porównania $z$ „Ogniem i mieczem” Henryka Sienkiewicza [w:] H. Bursztyńska (red.), Henryk Sienkiewicz: tradycja - kreacja - styl, Katowice 1982, s. 114-130; M. Zarębina, Porównania $w$ „Anielce” $i$ „Placówce” Bolesława Prusa, „Polonica” 1990, t. XV, s. 131-144; E. Młynarczyk, Porównanie w powieści W. Myśliwskiego „Kamień na kamieniu”, „Rocznik Naukowo-Dydaktyczny WSP w Krakowie. Prace Językoznawcze" t. VIII, s. 149-155; M. Pietrzak, Rośliny w porównaniach występujacych w „Trylogii” Henryka Sienkiewicza [w:] A. Dąbrowska (red.), Język a kultura, t. 16: Świat roślin w języku i kulturze, red. A. Dabrowska, Wrocław 2001, s. 169-179; M. Majewska, Porównania w „Urodzie życia” Stefana Żeromskiego (materiał badawczy z objaśnieniami), „Prace Filologiczne” 2004, t. XLIX, s. 317-346; U. Sokólska, Porównania charakteryzujace ludzi i zachowania ludzkie $w$ reportażach M. Wańkowicza, „Roczniki Humanistyczne” 2001/2002, z. 6, s. 391-402.

11 Zob. K. Burska, Porównanie jako przejaw językowej kreatywności dziennikarzy sportowych (na materiale z wortalu iGol.pl) [w:] A. Czapla, M. Koper (red.), Język $i$ sport, Lublin 2016, s. 41-59. 
paratywów w odmianie dziennikarsko-sportowej zwróciła także uwagę Karolina Czemplik ${ }^{12}$ i Beata Grochala. ${ }^{13} \mathrm{O}$ porównaniach w relacjach i komentarzach sportowych wspominali też w swoich pracach Mariusz Koper ${ }^{14}$ oraz Beata Jarosz. ${ }^{15}$

Według autorów Słownika terminów literackich porównanie to:

uwydatnienie jakichś właściwości opisywanego zjawiska przez wskazanie na jego podobieństwo do innego zjawiska. Porównanie jest dwuczłonową konstrukcją semantyczna sprzęgnięta wewnętrznie za pomoca wyrażeń: jak, jako, jak gdyby, na kształt, podobny, niby itp. Oba człony odznaczaja się przy tym pewna cecha semantyczna, motywująca porównanie i stanowiąca jego logiczna podstawę, tzw. tertium comparationis. W wyniku porównania zjawisko, o którym mowa, zostaje zinterpretowane poprzez pryzmat zjawiska, $\mathrm{z}$ którym je zestawiono. ${ }^{16}$

Zdaniem Františka Čermáka pełny schemat porównania zawiera następujące elementy: comparandum (przedmiot, zjawisko porównywane), relator (czasownik o szerokiej wartości kategorialnej, np. jest), tertium comparationis (określenie, na czym polega podobieństwo), comparator (łącznik porównania) i comparatum (człon porównujący). ${ }^{17} \mathrm{~W}$ konstrukcjach porównawczych opuszczeniu może ulec każdy z wymienionych wyżej elementów $z$ wyjątkiem comparatum, które jest koniecznym składnikiem każdego porównania.

W pracach polskich autorów, nierzadko zróżnicowanych pod względem metodologicznym oraz terminologicznym, zasadniczo wyróżnia się trzy podstawowe składniki porównania. Pierwszy to człon porównujący, odnoszący się do tego, co porównujemy (comparandum), drugi to człon porównywany, mający związek z tym, do czego porównujemy (comparans) i trzeci określany mianem funktora gramatycznego. Istotne jest również wyodrębnienie tzw. tertium comparationis, czyli wspólnej cechy

12 K. Czemplik, Czasami zaskakujacy, czasami zabawny, ale jakże oryginalny jezyk relacji sportowych Zimowych Igrzysk Olimpijskich Soczi 2014 [w:] K. Burska, B. Cieśla (red.), Kreatywność językowa w przestrzeni medialnej, Łódź 2014, s. 49-58.

13 B. Grochala, Kicz jako sposób wyrażania emocji (metaforyka radiowych relacji sportowych) [w:] B. Kudra, E. Szkudlarek-Śmiechowicz (red.), Kicz w języku i komunikacji, Łódź 2016, s. 335-342.

14 M. Koper, Emocje w języku sprawozdawców sportowych [w:] K. Wojtczuk, V. Machnicka (red.), Rejestr emocjonalny języka, Siedlce 2009, s. 67-76.

15 B. Jarosz, Sposoby wartościowania w wypowiedziach komentatorów siatkarskich [w:] M. Karwatowska, A. Siwiec (red.), Wartości i wartościowanie w badaniach nad językiem, Chełm 2012, s. 142.

16 M. Głowiński, T. Kostkiewiczowa, A. Okopień-Sławińska, J. Sławiński, Słownik terminów literackich, Wrocław 2002, s. 411.

17 Česka přirownání [w:] Slownik české frazeologie a idiomatiky. Přirownání, Praha 1983. Za: Z. Leszczyński, Doświadczenie tekstów sakralnych odbite w obiegowych porównaniach, „Eódzkie Studia Teologiczne” 1994, z. 3, s. 152. 
warunkującej logiczną podstawę znaczeniową członu porównywanego i porównujacego. ${ }^{18}$

Biorąc pod uwagę strukturę, w języku A. Kostry możemy wyróżnić komparatywa proste oraz złożone. Pierwsze składają się najczęściej z jednego bądź dwóch segmentów w członie porównującym i porównywanym. W comparandum ujawniony zostaje podmiot porównania oraz jego cecha, w comparatum zaś obiekt porównujący w postaci wyrażenia dwuskładnikowego (zazwyczaj przymiotnik + rzeczownik, rzeczownik + wyrażenie przyimkowe). Najczęstszym łącznikiem obydwu elementów jest forma zaimkowa jak:

Obrona Tysona śmierdzi jak dworcowa knajpa.

Sosnowski jest solidny jak kościelne drzwi.

Darek chodzi jak tygrys po klatce.

Bardzo często w pierwszym członie porównania pominięte jest comparandum. Przedmiot porównania występuje wówczas $\mathrm{w}$ formie podmiotu domyślnego. Określana jest jednak jego cecha lub czynność, która wykonał. W konstrukcjach tego typu występuje również relator, chociaż i on może zostać usunięty:

Jest wolny jak ketchup.

Walną jak młotem pneumatycznym.

Nie jest sztywny jak pomnik.

Zdarzają się również komparatywa, w których brakuje zarówno relatora, jak i podmiotu porównywanego. Pojawia się jedynie tertium comparationis, tj. wspólna cecha obydwu członów konstytuujących porównanie, relator (w niektórych pracach nazywany też funktorem) oraz rzeczownik pełniący funkcję comparatum:

Zażarty jak bulterier.

Wolny jak ketchup.

Znacznie obszerniejsza grupę stanowia porównania złożone, tj. składające się $z$ więcej niż dwóch składników w comparatum (członie porównującym). W członie porównywanym, nierzadko eliptycznym, występuje jedynie cecha lub czynność podmiotu. Staje się on bardziej czytelny przy uwzględnieniu szerszego kontekstu komentarza sportowego:

Namęczył się jak aktorzy filmów pornograficznych przy dialogach.

Porusza się niezdarnie jak wóz drabiniasty z pijanym woźnica.

Już strzegł zwycięstwa jak rekin następnego posiłku.

18 A. Kudra, Porównanie w poezji Tadeusza Różewicza (lata 1945-1950), „Acta Universitatis Lodziensis. Folia Litteraria Polonica” 2003, 6, s. 314. 
W bogatym repertuarze porównań A. Kostyry pojawiają się również i takie, które mają formę rozbudowaną zarówno w członie porównywanym, jak i porównującym:

On miał takie szanse na przetrwanie tej serii ciosów jak śnieżny bałwan na pustyni. Gołota wstrząsa Sandersem jak barman koktajlem $z$ wódki i miodu.

Lewis unikał walki jak ścigany listem gończym policjantów.

Przed tą walka $z$ Kliczką był odważny jak kogut na własnej grzędzie, odgrażał się, że zleje Kliczkę, który jak twierdzi, ma miękkie serce i szklaną szczękę.

Byrd w zeszłym roku stoczył zaledwie jedną walkę, stąd pojawiły się opinie, że może być zardzewiały jak sprowadzane przez Polaków samochody z Niemiec.

A. Kostyra stosuje również porównania, które mają rozbudowaną dwuskładnikowa strukturę w członie drugim. Składa się on wówczas $z$ typowego comparatum, uzupełnionego o zdanie współrzędnie złożone przeciwstawne lub podrzędnie złożone przydawkowe. Wypowiedzenia te moga dodatkowo charakteryzować całą strukturę porównania lub téz doprecyzowywać jeden $z$ jego członów:

Jest szeroki jak drzwi w kościele, ale nawet te drzwi mają w sobie więcej finezji.

Potężny, szeroki jak drzwi w kościele, ale czasami wydaje się, że drzwi mają w sobie więcej fantazji.

Wyglądał jak prezes jakiegoś banku centralnego, który obniżył oprocentowanie do zera.

W komparatywach zarówno prostych, jak i złożonych - wieloskładnikowych w komponencie porównawczym najczęściej funkcję łącznika przyjmuje zaimek komparator jak. Zdarzaja się jednak konstrukcje, w których łącznikiem jest inny funktor, np. niż:

Potrafi być bardziej paskudny niż przereklamowany wirus świńskiej grypy.

W mówionych wariantach wypowiedzi A. Kostyry można odnotować osobliwe konstrukcje komparatystyczne, które wprawdzie nie zawieraja łącznika porównania, jednak ich wyraźnie dwuskładnikowa budowa (człon porównywany i porównujący) wskazuje na strukturę porównawcza. ${ }^{19}$ Funkcję komparatora pełni tutaj czasownik przypominać:

Twarz Amerykanina przypomina już carpaccio.

Marin jest jednak bardzo powolny. Przypomina wóz wypełniony kapustą.

Połowa twarzy Barrery przypomina krwawa maskę.

Poza figura językowo-stylistyczna, która jest porównanie, w języku mówionym A. Kostyry występują konstrukcje składniowe o charakte-

19 O osobliwych komparatorach pisze m.in. Maria Joka. Zob. M. Joka, Indywidualne warianty comparatora $w$ twórczości Jana Parandowskiego, „Roczniki Humanistyczne" 2001-2002, t. XLIX-L, s. 145-158. 
rze porównawczym. ${ }^{20}$ Nie przyjmują one struktury typowych komparacji, lecz wypowiedzeń podrzędnie złożonych, w których pełne zrozumienie znaczeniowej zawartości zdania nadrzędnego uzależnione jest od umieszczonego na tle porównawczym zdania podrzędnego. Niektóre $z$ wypowiedzeń to struktury wielokrotnie złożone:

Wydaje się, że jest tak silny, że mógłby iść na zderzenie $z$ czołgiem, ze szkodą dla czołgu.

Gołota prezentował się rewelacyjnie, wydawał się tak silny, że mógłby chyba przenieść górę do Mahometa.

On ma tak wielkie doświadczenie, że w jego narożniku mógłby stać nawet Michael Jackson, a on walczyłby tak samo.

Oni momentami poruszają się tak, jakby uciekli $z$ domu starców.

Był porozbijany tak, że można by go hospitalizować w szpitalu dla weteranów wojennych.

Podsumowując tę szkicowo nakreślona problematykę związaną $z$ budową komparatywów, należy zauważyć, iż struktury porównawcze zgromadzone na potrzeby niniejszego artykułu dostarczaja komparacji prostych oraz rozbudowanych zarówno w komponencie porównywanym, jak i porównującym. W materiale językowym nie odnotowano porównań wieloskładnikowych, które w literaturze przedmiotu określane sa mianem homeryckich. Jest to zrozumiałe, gdyż, o czym jeszcze będzie mowa, w języku A. Kostyry dominuja komparatywa potoczne oraz wysoce zindywidualizowane. Te ostatnie, tworzone ad hoc lub przygotowywane wcześniej na użytek widowiska sportowego, wydaja się najbardziej typowe dla tego dziennikarza.

\section{SEMANTYKA PORÓWNAŃ}

W literaturze przedmiotu wyróżnia się porównania potoczne, utarte, szablonowe oraz oryginalne struktury komparatystyczne. Pierwsze sa formacjami stosunkowo łatwymi do zinterpretowania, gdyż opieraja na naszych bezpośrednich doświadczeniach oraz obserwacji otaczajacej nas rzeczywistości. W drugiej grupie mieszczą się porównania nierzadko wykorzystujace odległe i bardzo zaskakujace asocjacje. $Z$ uwagi na swoją oryginalność i wyjątkowość nazywane sa porównaniami poetyckimi. ${ }^{21} \mathrm{~W}$ tekstach medialnych moga one $z$ jednej strony świadczyć o nieszablonowości, oryginalności twórcy, jego kreatywności, kompetencji i wyobraźni językowej, $z$ drugiej jednak strony, $z$ uwagi na swoja pre-

20 Zob. Z. Klemensiewicz, Zarys składni polskiej, Warszawa 1957, s. 85, 87, 90.

21 H. Kurkowska, S. Skorupka, Stylistyka polska. Zarys, Warszawa 1959, s. 202 . 
tensjonalność, kolokwializm i nieczytelny charakter, mogą wywoływać stylistyczny zgrzyt, a nawet zbliżać się do językowego kiczu.

W relacjach A. Kostyry zdecydowanie dominuja konstrukcje oryginalne, będacce wytworem zaskakującej wyobraźni samego autora oraz często przekraczające doświadczenie życiowe i językowe potencjalnego odbiorcy. Aby dobrze prześledzić wzajemne relacje komponentów porównania, należy przeanalizować zarówno comparandum (przedmiot, zjawisko porównywane), jak i comparatum (człon porównujący).

$Z$ uwagi na fakt, że mówione warianty wypowiedzi pochodzą $z$ relacji bokserskich, obiektami porównań są najczęściej sami pięściarze, rzadziej ich trenerzy, sędziowie walk czy zgromadzona w obiekcie sportowym publiczność. Sportowcy oraz ich zmagania na arenach ringowych poddawani sa subiektywnej ocenie dziennikarskiej. Bywa ona dwojaka: nobilitująca lub deprecjonująca. ${ }^{22}$ Obrazuja to najczęściej przymiotniki lub przysłówki będące w wypadku porównań A. Kostyry nieodłączną częscią comparandum:

Porusza się niezdarnie jak wóz drabiniasty z pijanym woźnica.

Zażarty jak bulterier jest Sidorenko.

Ręce ma szybkie jak złodziej kieszonkowy w warszawskim metrze.

Był gładki do odczytania jak otwarta księga.

Jest ostrożny jak bankier udzielający kredytu hipotecznego w czasach kryzysu.

Ocenę umiejętności bokserskich obrazują też czasowniki. Właściwe odczytanie zalet bądź wad możliwe jest jednak dopiero po uwzględnieniu znaczenia drugiego członu (comparatum). W wypadku porównań A. Kostyry $z$ reguly jest to ocena negatywna:

Rusza się jak wóz drabiniasty wypełniony po brzegi burakami cukrowymi.

Hipnotyzuje przeciwników jak wąż kurczaka. $Z$ bliska.

Już strzegł zwycięstwa jak rekin następnego posiłku.

Byrd okopał się w obronie jak Francuzi na linii Maginota.

Najbardziej charakterystyczną cechą porównań A. Kostyry jest stosowanie oryginalnego i zaskakującego obrazowania umiejętności bokserskich. Jest ono zestawiane $z$ różnorakimi dziedzinami współczesnego świata. Drugi z głównych członów porównania (comparatum) przynależy

22 O nobilitowaniu lub deprecjonowaniu sportowców oraz ich zachowań pisały m.in. Beata Grochala i Magdalena Makowska. Zob. B. Grochala, Sposoby nobilitowania $i$ deprecjonowania zawodników $i$ ich zachowan $w$ komentarzach sportowych [w:] R. Bizior, D. Suska (red.), Zjawisko nobilitacji i deprecjacji w tekście. Komunikacja, Częstochowa 2012, s. 31-47; przedruk [w:] M. Kita, I. Loewe (red.), Język w telewizji. Antologia, Katowice 2016, s. 239-254; M. Makowska, Medialne igrzyska. O jezzykowych i pozajezzykowych sposobach nobilitowania $i$ deprecjonowania sportowców na przykładzie relacji z Letnich Igrzysk Olimpijskich z Rio de Janeiro, „Tekst i Dyskurs” 2017, nr 10, s. 63-81. 
bowiem do różnych kręgów tematycznych. Są to m.in. konstrukcje porównawcze $z$ komponentami: przyrodniczym, cywilizacyjno-kulturowym, historycznym, antropologicznym, militarnym. Oto kilkanaście przykładów:

Nooo widzieliśmy w końcu w tej rundzie lewy prosty, rzadki jak deszcz na Saharze.

On miał takie szanse na przetrwanie tej serii ciosów jak śnieżny bałwan na pustyni.

Każdy człowiek musi się wyszumieć jak drzewo.

Darek chodzi jak tygrys po klatce.

Austin przed walka $z$ Kliczka był odważny jak kogut na własnej grzędzie.

Hipnotyzuje przeciwników jak wąż kurczaka. $Z$ bliska.

Ciosy spływaja po Sandersie jak woda po kaczce.

Byrd okopał się w obronie jak Francuzi na linii Maginota

Rzadko się myli Jackiewicz. Te jego ciosy sa jak bomby wyprowadzane laserem.

Morales ma wzrok mętny jak dwudniowe piwo.

Jego prowadzenie jest tak mało widoczne jak pierwszy zarost nastolatka.

Wałujew technicznie jest słaby jak szpadel ze złamanym członkiem.

Wyróżnione pola semantyczne, które występują w comparatum, można uszczegółowić w odniesieniu do świata natury i kultury. W wypadku przyrody autor $m$.in. sięga po rozwiązania $z$ komponentem klimatycznym, florystycznym, animalistycznym. W polu kulturowym tworzy porównania kulinarne, związane $z$ konkretnymi obiektami kultury materialnej, wreszcie przedmiotami codziennego użytku. W swoich porównaniach dziennikarz $z$ chęcia sięga też do świata ekonomii czy biznesu:

Wyglądał jak prezes jakiegoś banku centralnego, który obniżył oprocentowanie do zera.

Jest ostrożny jak bankier udzielający kredytu hipotecznego w czasach kryzysu.

Nierzadko też odwołuje się do postaci ze świata nauki, polityki i rozrywki. Moga to być zarówno konkretne osoby, jak i wykonywane przez nie zawody:

Byrdowi trener potrzebny jest mniej więcej tak jak Einsteinowi nauczyciel matematyki.

On ma tak wielkie doświadczenie, że w jego narożniku mógłby stać nawet Michael Jackson, a on walczyłby tak samo.

I znów czepia się Polaka jak minister Pitera posła za 5,40.

Pojedynki nudne jak nauczanie matematyki w liceum.

Ma ręce szybkie jak złodziej kieszonkowy w warszawskim metrze.

Pewnym wyznacznikiem stylu dziennikarskiego A. Kostyry jest stosowanie ironii. Znajduje ona odzwierciedlenie także w porównaniach komentatora walk bokserskich. Bardzo dobrze ten trudny do sklasyfikowania mechanizm językowo-semantyczny oddaja następujące komparacje:

Namęczył się jak aktorzy filmów pornograficznych przy dialogach.

Oni się lubia jak listonosz z bulterierem. 
Obydwie egzemplifikacje pozostają w zgodzie $z$ klasyczną definicją ironii. Autorzy Słownika terminów literackich traktuja ja jako:

właściwość stylu polegająca na sprzeczności między dosłownym znaczeniem wypowiedzi a jej znaczeniem właściwym, nie wyrażonym wprost, ale zamierzonym przez autora i zazwyczaj rozpoznawalnym dla odbiorcy. ${ }^{23}$

Jak słusznie zauważa K. Burska, w tego typu konstrukcjach dostrzeżenie sprzeczności między dosłownym znaczeniem komunikatu a pożądana przez dziennikarza interpretacja możliwe jest dopiero wtedy, gdy odbiorca zrozumie rzeczywistość pozajęzykową, do której odwołuje się autor komparacji. ${ }^{24}$

\section{FUNKCJA PORÓWNAŃ}

Konstrukcje porównawcze $\mathrm{w}$ mówionych wariantach wypowiedzi A. Kostyry pełnia kilka funkcji. Nie wszystkie $z$ nich ujawniaja się w jednakowym stopniu. Wydaje się, że najważniejsza jest funkcja komunikatywna. Komentarz sportowy jest bowiem pewna forma przekazu na linii nadawca (narrator transmisji) - odbiorca (telewidz). Poza obrazem telewizyjnym jego zadaniem jest więc ułatwienie oraz zrozumienie istoty widowiska sportowego (w tym wypadku zawodów bokserskich). Nie mniej istotna jest funkcja poznawcza. Porównania pozwalaja

wydobyć nowe odcienie znaczeniowe ze słów, pozwalają odnieść to, co nieznane, do tego, co znane, pozwalaja abstrakcję sprowadzić do konkretu, rzecz niewyobrażalna - do wyobrażalnej. ${ }^{25}$

Przez stosowanie oryginalnych porównań dziennikarz sportowy nie tylko wprowadza nowe elementy obrazowe, ale także pewne sugestie i stany emocjonalne, które towarzyszą mu w trakcie oglądania zawodów bokserskich. Dzięki nim komentarz sportowy nierzadko przyjmuje charakter emfatyczny. W ten sposób ujawnia się funkcja oceniająca (nobilitująca lub deprecjonująca sportowców) oraz przede wszystkim funkcja ekspresywna. Ta ostatnia jest jednym $z$ podstawowych wyznaczników mówionych wariantów środowiskowo-profesjonalnych (odmian dziennikarsko-sportowych). Poza stricte komunikacyjnym wymiarem komentarza, jak również jego funkcją poznawcza (dydaktyczna), istotna jego cechą jest także uatrakcyjnienie widowiska sportowego potencjalnemu odbiorcy

${ }^{23}$ M. Głowiński, T. Kostkiewiczowa, A. Okopień-Sławińska, J. Sławiński, op. cit., s. 221.

${ }^{24}$ K. Burska, op. cit., s. 51.

${ }^{25}$ M. Głowiński, A. Okopień-Sławińska, J. Sławiński, Zarys teorii literatury, Warszawa 1991, s. 111. 
(kibicowi). Stosowanie wyszukanych konstrukcji porównawczych, inkrustowanie wypowiedzi zaskakujacymi konotacjami ujawniaja w tym przekazie funkcję poetycka. Autoteliczność komentarza, kreatywność oraz oryginalność jego twórcy wysuwa wówczas formę językowa na pierwszy plan. Bezpośrednio $z$ funkcją estetyczną koresponduje funkcja ludyczna. Porównania mogą bowiem służyć rozbawieniu odbiorcy, a co za tym idzie - zyskaniu jego sympatii. ${ }^{26}$ Każdorazowo dobór środków językowych oraz ich bogaty repertuar może być jednak poddawany zróżnicowanej ocenie.

\section{PRÓBA OCENY}

W mówionych wariantach wypowiedzi A. Kostyry zdecydowanie przeważaja porównania wysoce zindywidualizowane. Bardzo rzadko występują komparatywa utarte i potoczne. Można więc powiedzieć, że dziennikarz ten wykazuje się znaczną inwencją twórczą i kreatywnością językowa. Jego język jest niezwykle barwny i nieskonwencjonalizowany. Biorąc pod uwagę repertuar środków językowych, w opinii piszącego te słowa, obok struktur udanych trafiaja się i takie, które budzą wątpliwości. Ich szczegółowa ocena wymagałaby prześledzenia tertium comparationis oraz relacji podobieństwa członu porównywanego $z$ porównujacym. Przykładowo, o ile porównanie solidny jak kościelne drzwi, odsyłające odbiorcę do rzeczywistości pozajęzykowej, wydaje się dość trafne i czytelne, o tyle określenie boksera mianem wolnego jak ketchup jest już dyskusyjne. Nadmiar struktur porównawczych oraz nie zawsze ich trafność sprawia, że komentator walk bokserskich przekracza czasami granice świeżości stylistycznej. Jak zauważa Jan Miodek,

określenie owej granicy jest bardzo trudne. Tylko umiejętność zobiektyzowania przeżywanych emocji i doświadczenie stylistyczne moga uchronić przed jej przekroczeniem. ${ }^{27}$

Budowanie komparatywów na podstawie bardzo odległych skojarzeń $z$ jednej strony może zatem świadczyć o bogatej wyobraźni autora, $z$ drugiej zaś dowodzić braku wyczucia językowego.

$Z$ pewnościa A. Kostyra jako dziennikarz nie tylko telewizyjny, ale również prasowy i internetowy jest świadomy specyfiki swojego oryginalnego języka oraz nadmiaru konstrukcji porównawczych. Być może w ten sposób chce pozostać nietuzinkowy i rozpoznawalny. Atrakcyjny, nieszablonowy przekaz $z$ reguły gromadzi bowiem większą widownię,

26 K. Burska, op. cit., s. 57.

27 J. Miodek, O języku do kamery, Rzeszów 1992, s. 94; M. Koper, 2003, „Poezja futbolu”. Kilka uwag o języku sprawozdawców sportowych [w:] W. Książek-Bryłowa, H. Duda (red.), Język polski. Współczesność. Historia, Lublin, s. 51-62. 
sama zaś dyskusja wokół tej specyficznej narracji wywołuje pewne emocje. Wszystkie konstrukcje porównawcze wpisuja się w poetykę odmiany dziennikarsko-sportowej. W wypadku języka A. Kostyry być może sa nawet przejaskrawieniem tego, co się obecnie dzieje w profesjolekcie dziennikarskim. W opinii piszącego te słowa nadmiar tropów stylistycznych, emfatyczny charakter narracji może wreszcie prowadzić do językowego ekshibicjonizmu. Oceniając w sposób subiektywny Paganiniego sportowego mikrofonu (tak nazywaja dziennikarza zwolennicy jego relacji), można odnieść wrażenie, że albo jego skrzypce nie zawsze dobrze stroja, albo są słabej marki, albo też sam wirtuoz dokonuje zbyt wielu eksperymentów w trakcie koncertu. Niewatpliwie „sportowy altowiolista” przykuwa swoim językiem uwagę odbiorców, czego dowodem jest także ten artykuł. Ekstrawagancja językowa, która przesłania samo widowisko bokserskie, może w istocie nie ułatwiać, ale komplikować jego odbiór.

\section{PODSUMOWANIE}

Barwny język A. Kostyry wpisuje się w relacje innych dziennikarzy sportowych, którzy często posługują się leksyką emocjonalną, zindywidualizowana i nasaczona tropami stylistycznymi. Jak pokazują badania innych odmian językowych, nie jest to wyłącznie specyfika relacji sportowej. Przykładem może być współczesny język religijny, w którym występujące wysoko zindywidualizowane komparatywa bardzo często przekraczaja potoczne doświadczenie życiowe i językowe odbiorcy. ${ }^{28}$ Wszystkie te cechy znajduja odzwierciedlenie w relacjach A. Kostyry, który zapewne w sposób świadomy uznał porównanie za ulubiony trop stylistyczny oraz wyznacznik swoich wypowiedzi. Komparacje oraz ich zaskakujący charakter polega na wykorzystywaniu całego wachlarza skojarzeń zwiazanych $z$ natura, kultura, religia i społeczeństwem. Jak zauważa K. Burska, wiele $z$ nich to konstrukcje absurdalne, sięgające głębokich pokładów ludzkiej wyobraźni. Uwidacznia się w nich zarówno sięganie po zakorzenione w języku i kulturze stereotypy, jak też utrwalone wzorce społeczne. Wszystkie struktury porównawcze maja za zadanie uatrakcyjnić i ubarwić przebieg sportowego widowiska. ${ }^{29}$

Autor niniejszego artykułu nie rości sobie pretensji do pełnego omówienia przedstawionej problematyki zarówno w odniesieniu do konstrukcji porównawczych w języku mówionym A. Kostyry, jak i w ogólnym

28 M. Nowak, Porównania we współczesnym języku religijnym (na podstawie tekstów nieartystycznych), „Poznańskie Spotkania Językoznawcze” 2004, t. XIII, s. 101.

${ }^{29} \mathrm{~K}$. Burska, $Z$ Czuba i na żywo - językowe sposoby kształtowania relacji sportowych na żywo na portalu internetowym www.zczuba.pl [w:] M. Jarosz, P. Drzewiecki, P. Płatek (red.), Sport w mediach, Warszawa 2013, s. 59. 
zastosowaniu tej figury stylistycznej w dziennikarstwie sportowym. Złożony charakter tych konstrukcji, ich wielofunkcyjność, niejednolitość formalna i znaczeniowa oraz różnorodne zastosowanie $z$ pewnością będa jeszcze niejednokrotnie przedmiotem badań i szczegółowych analiz. Szkic, w którym dokonano pobieżnie semantycznej, strukturalno-gramatycznej i funkcjonalnej analizy dziennikarskich komparatywów wymaga pogłębionych badań m.in. na podstawie ustaleń współczesnej kognitywistyki czy retoryki. Niezbędna wydaje się również dogłębna analiza wszystkich odmian języka sportowego, uwzględniająca profesjolekt wielu dziennikarzy sportowych.

\section{Bibliografia}

K. Burska, 2013, Z Czuba i na żywo - językowe sposoby kształtowania relacji sportowych na żywo na portalu internetowym www.zczuba.pl [w:] M. Jarosz, P. Drzewiecki, P. Płatek (red.), Sport w mediach, Warszawa, s. 46-72.

K. Burska, 2016, Porównanie jako przejaw językowej kreatywności dziennikarzy sportowych (na materiale $z$ wortalu iGol.pl) [w:] A. Czapla, M. Koper (red.), Język $i$ sport, Lublin, s. 41-59.

D. Buttler, 1977, Porównania w twórczości Żeromskiego [w:] Z. Goliński (red.), Stefan Żeromski. W pięćdziesiąta rocznice śmierci. Studia i szkice, Warszawa, s. $258-276$.

K. Czemplik, 2014, Czasami zaskakujacy, czasami zabawny, ale jakże oryginalny język relacji sportowych Zimowych Igrzysk Olimpijskich Soczi 2014 [w:] K. Burska, B. Cieśla (red.), Kreatywność językowa w przestrzeni medialnej, Łódź, s. 49-58.

Česka přirownání [w:] Slownik české frazeologie a idiomatiky. Přirownání, Praha 1983.

Z. Gałecki, 2012, Slavek $i$ Slavko - nazwy maskotek Mistrzostw Europy $w$ Piłce Nożnej 2012, „Roczniki Humanistyczne” t. LX, z. 6, s. 87-95.

Z. Gałecki, 2014, „Czyste szaleństwo”-współczesna piosenka okolicznościowa. Liber i zespół InoRos [w:] J. Kuć, K. Wojtczuk (red.), Język a muzyka. Ujęcie filologiczne i muzykologiczne, Siedlce, s. 23-29.

M. Głowiński, T. Kostkiewiczowa, A. Okopień-Sławińska, J. Sławiński, 2002, Słownik terminów literackich, Wrocław.

M. Głowiński, A. Okopień-Sławińska, J. Sławiński, 1991, Zarys teorii literatury, Warszawa.

B. Grochala, 2012, Sposoby nobilitowania i deprecjonowania zawodników i ich zachowań w komentarzach sportowych [w:] R. Bizior, D. Suska (red.), Zjawisko nobilitacji i deprecjacji w tekście. Komunikacja, Częstochowa, s. 31-47; przedruk [w:] M. Kita, I. Loewe (red.), Język w telewizji. Antologia, Katowice 2016, s. 239-254.

B. Grochala, 2015, Telewizyjna transmisja sportowa jako kolekcja gatunków [w:] D. Ostaszewska, J. Przyklenk (red.), Gatunki mowy i ich ewolucja, t. 5: Gatunek a granice, Katowice, s. 347-355.

B. Grochala, 2016, Telewizyjna transmisja sportowa w ujęciu genologii lingwistycznej na materiale meczów piłki nożnej, Łódź. 
B. Grochala, 2016, Kicz jako sposób wyrażania emocji (metaforyka radiowych relacji sportowych) [w:] B. Kudra, E. Szkudlarek-Śmiechowicz (red.), Kicz w języku i komunikacji, Łódź, s. 335-342.

B. Jarosz, 2012, Sposoby wartościowania w wypowiedziach komentatorów siatkarskich [w:] M. Karwatowska, A. Siwiec (red.), Wartości i wartościowanie $w$ badaniach nad językiem, Chełm, s. 133-144.

M. Joka, 2001-2002, Indywidualne warianty comparatora $w$ twórczości Jana Parandowskiego, „Roczniki Humanistyczne” t. XLIX-L, s. 145-158.

Z. Klemensiewicz, 1957, Zarys składni polskiej, Warszawa.

M. Koper, 2003, „Poezja futbolu”. Kilka uwag o języku sprawozdawców sportowych [w:] W. Książek-Bryłowa, H. Duda (red.), Język polski. Współczesność. Historia, Lublin, s. 51-62.

M. Koper, 2009, Emocje w języku sprawozdawców sportowych [w:] K. Wojtczuk, V. Machnicka (red.), Rejestr emocjonalny języka, Siedlce, s. 67-76.

M. Koper, 2012, Peryfrazy w języku komentatorów sportowych, „Roczniki Humanistyczne" t. 60, z. 6, s. 113-112; przedruk [w:] M. Kita, I. Loewe (red.), Język $w$ telewizji. Antologia, Katowice 2016, s. 217-226.

M. Koper, 2016, Język sportu-problematyka badawcza [w:] A. Czapla, M. Koper (red.), Język i sport, Lublin, s. 13-40.

M. Koper, 2019, Polska dawaj! O języku piłkarskiego hasła oraz jego bliższych $i$ dalszych konotacjach, „Poradnik Językowy” z. 1, s. 95-105.

A. Kostyra, 2017, Walki stulecia. Bohaterowie wielkiego boksu, Kraków.

A. Kudra, 2003, Porównanie w poezji Tadeusza Różewicza (lata 1945-1950), „Acta Universitatis Lodziensis. Folia Litteraria Polonica” 6, s. 313-321.

H. Kurkowska, S. Skorupka, 1959, Stylistyka polska. Zarys, Warszawa.

Z. Leszczyński, 1994, Doświadczenie tekstów sakralnych odbite $w$ obiegowych porównaniach, „Łódzkie Studia Teologiczne” z. 3, s. 151-163.

I. Loewe, 2014, Sport $w$ mediasferze z perspektywy lingwisty, „Postscriptum Polonistyczne" nr 2 (14), s. 71-91.

I. Loewe, 2020, Sport, medium, dyskurs telewizyjny. Mediolingwistyczne rozważania o wpływie, „Zeszyty Prasoznawcze” t. 63, nr 2 (242), s. 31-46.

M. Majewska, 2004, Porównania w „Urodzie życia” Stefana Żeromskiego (materiał badawczy z objaśnieniami), „Prace Filologiczne” t. XLIX, s. 317-346.

M. Makowska, 2017, Medialne igrzyska. O językowych i pozajęzykowych sposobach nobilitowania i deprecjonowania sportowców na przykładzie relacji z Letnich Igrzysk Olimpijskich z Rio de Janeiro, „Tekst i Dyskurs” nr 10, s. 63-81.

B. Mikołajczak, 1976, Porównania w „Faraonie” Bolesława Prusa, „Studia Polonistyczne" t. III, s. 105-114.

J. Miodek, 1992, O języku do kamery, Rzeszów.

E. Młynarczyk, 1994, Porównanie w powieści W. Myśliwskiego „Kamień na kamieniu”, „Rocznik Naukowo-Dydaktyczny WSP w Krakowie. Prace Językoznawcze" t. VIII, s. 149-155.

Z. Mokranowska, 1982, Porównania z „Ogniem i mieczem” Henryka Sienkiewicza [w:] H. Bursztyńska (red.), Henryk Sienkiewicz: tradycja-kreacja-styl, Katowice, s. 114-130.

M. Nowak, 2004, Porównania we współczesnym języku religijnym (na podstawie tekstów nieartystycznych), „Poznańskie Spotkania Językoznawcze” t. XIII, s. 91-101. 
M. Pietrzak, 2001, Rośliny w porównaniach występujacych w „Trylogii” Henryka Sienkiewicza [w:] A. Dabrowska (red.), Język a kultura, t. 16: Świat roślin w języku i kulturze, Wrocław, s. 169-179.

J. Podracki, 1978, Wpływ słownictwa sportowego na inne odmiany polszczyzny, „Kultura Fizyczna” nr 6, s. 265-269.

K. Siekierska, 1981, Porównania w „Wojnie chocimskiej” Wacława Potockiego i w „Pamiętnikach” Jana Chryzostoma Paska, „Polonica” t. VII, s. 233-254.

U. Sokólska, 2001/2002, Porównania charakteryzujace ludzi i zachowania ludzkie $w$ reportażach $M$. Wańkowicza, „Roczniki Humanistyczne” z. 6, s. 391-402.

M. Zarębina, 1990, Porównania w „Anielce” i „Placówce” Bolesława Prusa, „Polonica" t. XV, s. 131-144.

L. Zieliński, 2002, Wpływ słownictwa sportowego na język polityki [w:] G. Szpila (red.), Język a komunikacja 4. Zbiór referatów z konferencji pt. Język trzeciego tysiąclecia II (Kraków, 28 lutego-2 marca 2002), t. I: Nowe oblicza komunikacji we współczesnej polszczyźnie, Kraków, s. 261-270.

\section{Knockout is unavoidable here like wrinkles in your sixties. A few comments on the comparative formations in utterances by Andrzej Kostyra, a sports journalist}

\section{Summary}

In this paper, an analysis of selected issues related to comparative formations occurring in utterances by Andrzej Kostyra, a sports journalist, are presented. Simple and then complex comparatives have been analysed. As regards the semantic analysis, semantic fields of comparative components have been presented and their functions have been identified and assessed subjectively.

Keywords: comparison - language of sport - commentary - relation - utterances - journalist.

Trans. Monika Czarnecka 